\title{
GAMBARAN KETAKUTAN ANAK USIA PRASEKOLAH AKIBAT HOSPITALISASI
}

\author{
Tivanny Natalia Putri ${ }^{1}$, Wahyu Rima Agustin ${ }^{2}$, Noerma Shovie Rizqiea ${ }^{3}$ \\ 1,2,3 Program Studi Sarjana Keperawatan dan \\ Profesi Ners Universitas Kusuma Husada Surakarta \\ nataliaputri192@gmail.com
}

\begin{abstract}
ABSTRAK
Hospitalisasi adalah keadaan ketika anak menjalani perawatan dan prosedur di rumah sakit. Perasaan takut pada anak usia prasekolah terhadap hospitalisasi disebabkan oleh kegelapan, hantu, dan pengalaman yang menyakitkan. Saat dirawat di rumah sakit anak menghadapi lingkungan yang asing dan pemberi asuhan yang tidak mereka kenal, baik itu para medis maupun perawat. Penelitian ini bertujuan untuk mengetahui gambaran ketakutan anak usia prasekolah akibat hospitalisasi. Penelitian ini menggunakan Metode Observasional dengan Desain Deskriptif. Teknik sampel dalam penelitian ini menggunakan Teknik Total Sampling dengan jumlah 19 responden, anak usia 3-6 tahun di Rumah Sakit Panti Waluyo Surakarta. Penelitian ini menggunakan kuesioner CMFS-R (Child Medical Fear Scale Revised). Hasil penelitian ini menunjukkan bahwa jumlah anak yang mengalami ketakutan dengan tingkat sangat takut sebanyak 14 responden $(73,7 \%)$ dan tidak takut sama sekali terdapat 5 responden $(26,3 \%)$. Karakteristik responden berdasarkan usia yaitu rata-rata 4,37 tahun dan karakteristik berdasarkan jenis kelamin yaitu anak berjenis kelamin perempuan 11 responden (57,9\%). Reaksi ketakutan pada anak antara lain menolak prosedur rumah sakit, menjerit keras, menangis dan menyerang orang lain. Penelitian disimpulkan bahwa ketakutan anak akibat hospitalisasi di ruang Bakung Rumah Sakit Panti Waluyo Surakarta terbanyak dalam kategori sangat takut. Penelitian ini diharapkan dapat menjadi bahan referensi bagi penelitian selanjutnya dan dapat ditambahkan intervensi sebagai terapi ketakutan pada anak
\end{abstract}

Kata kunci : anak prasekolah, hospitalisasi, ketakutan

\begin{abstract}
Hospitalization is a condition when children experience treatment and procedures in the hospital. Darkness, ghosts, and painful experiences caused the hospitalization fear of children's feelings. While being admitted to the hospital, children meet an unfamiliar environment and caregivers that they do not know either the medics or the nurses. The objective of this research is to investigate the fear of preschool children due to hospitalization. This study adopted an observational research method with a descriptive design. A total sampling chosen 19 children aged 3-6 years at Panti Waluyo Hospital of Surakarta. The instruments used for data collection were CMFS-R (Child Medical Fear Scale-Revised) questionnaire. The result revealed that children with a level of too fearful were 14 respondents (73.7\%), and no fear was five respondents $(26.3 \%)$. The average age of children's characteristics was 4.37 years, and gender aspects were female with 11 respondents $(57.9 \%)$. Fear reactions in children were refusing hospital procedures, screaming, crying, and attacking others. This study categorized the children's fear due to hospitalization in the Bakung room at Panti Waluyo Hospital of Surakarta as too fearful. This research is expected to be source material for further investigation and can combine interventions as children's fear therapy.
\end{abstract}

Keywords: fear, hospitalization, preschool children 


\section{PENDAHULUAN}

Periode kanak-kanak awal merupakan tahap tumbuh kembang yang terdiri atas usia 1-3 tahun (toddler), 3-6 tahun (prasekolah). Perkembangan konsep diri usia prasekolah dan kemampuan interaksi sosial anak sudah lebih luas sehingga anak dapat mempersiapkan diri untuk memasuki dunia sekolah (Suryanti \& Yulistianti, 2012).

Berdasarkan data anak usia prasekolah menurut data World Health Organisation (WHO) pada tahun 2015 sebanyak 45\% dari keseluruhan jumlah pasien anak usia prasekolah yang dihospitalisasi (Padila et al., 2019). Berdasarkan data Badan Pusat Statistik (BPS) tahun 20162018 jumlah anak usia 0-4 tahun yang mengalami hospitalisasi pada tahun 2018 sebanyak 6,22\%, dan di usia 5-9 tahun 2,89\% dari jumlah total penduduk Indonesia. Di Provinsi Jawa Tengah hospitalisasi anak sebesar 4,1\% dari jumlah penduduk, persentase tertinggi anak yang pernah dirawat inap ada di perkotaan dibandingkan dengan di pedesaan (BPS, 2018).

Anak yang menjalani hospitalisasi akan mengalami kecemasan dan stres. Hal itu diakibatkan oleh adanya perpisahan, kehilangan kontrol, ketakutan karena tinggal di lingkungan yang asing dan rasa sakit pada tubuhnya (Saputro \& Fazrin, 2017).

Hospitalisasi juga dapat menimbulkan perubahan yang negative yaitu anak akan takut dengan lingkungan baru, hilang kontrol terhadap dirinya sendiri, anak lebih sering menangis, manja, dan agresif, mengalami depresi dan regresi atau kemunduran perkembangan. Reaksi tersebut dipengaruhi oleh usia perkembangan, pengalaman sebelumnya dengan penyakit, perpisahan, atau hospitalisasi (Susanti \& Hendika, 2013)

Perasaan takut pada anak usia prasekolah saat menjalani hospitalisasi lebih dominan dibandingkan pada anak usia sekolah, karena pada anak usia sekolah lebih takut diculik (Kyle \& Carman, 2017).

Anak usia prasekolah memiliki imajinasi yang aktif sehingga menyebabkan rasa takut dan terancam ketika anak terkena paparan fisik, seperti disuntik. (Ramdaniati, 2011)

Berdasarkan studi awal yang dilakukan oleh peneliti didapatkan data dari rekam medik (RS Panti Waluyo 7 Oktober 2019) tanggal 1 Juli sampai 30 September 2019 tercatat ada 93 anak usia prasekolah yang menjalani rawat inap.

Tujuan dari penelitian ini adalah untuk mengetahui gambaran ketakutan anak usia prasekolah akibat hospitalisasi.

\section{METODOLOGI}

Penelitian ini dilaksanakan di Rumah Sakit Panti Waluyo Surakarta. Penelitian ini menggunakan Metode Observasional dengan Desain Deskriptif. Teknik sampel menggunakan Teknik Total Sampling dengan jumlah sampel 19 responden. Kriteria inklusi dalam penelitian ini adalah anak yang diizinkan oleh orangtuanya untuk menjadi responden, orang tua dapat membaca dan menulis, anak yang dapat diajak berbicara atau berkomunikasi, anak pada usia prasekolah (3-6 tahun), anak yang sadar atau tidak dalam keadaan koma, anak yang dirawat minimal 1 hari dan maksimal 7 hari. Kriteria eksklusi dalam penelitian ini yaitu kondisi lemah (tidak adanya kegairahan, pucat, nafsu makan menurun), menjalani perawatan intensif.

Instrumen yang digunakan dalam penelitian ini adalah menggunakan kuesioner CMFS-R (Child Medical Fear Scale-Revised). Saat anak menjalani rawat inap di rumah sakit minimal 1 hari dan maksimal 7 hari diukur ketakutan anak tersebut saat menjalani hospitalisasi menggunakan kuesioner CMFS-R.

\section{HASIL}

Hasil yang didapatkan pada penelitian ini 
adalah :

Tabel 1. Distribusi Karakteristik usia $(n=19)$

\begin{tabular}{lccc}
\hline & \multicolumn{3}{c}{ Nilai } \\
\hline Usia & Min & Max & Mean \\
\hline Jumlah & 3 & 6 & 4,37 \\
\hline
\end{tabular}

Tabel 2. Karakteristik Responden Berdasarkan Jenis Kelamin.

\begin{tabular}{lcc}
\hline Jenis kelamin & f & \% \\
\hline Laki-laki & 8 & 42,1 \\
Perempuan & 11 & 57,9 \\
\hline Jumlah & 19 & 100 \\
\hline
\end{tabular}

Tabel 3. Karakteristik Responden Berdasarkan Ketakutan Anak (n=19).

\begin{tabular}{lcc}
\hline Ketakutan anak & f & \% \\
\hline Sangat takut & 14 & 73,7 \\
Tidak takut sama sekali & 5 & 26,3 \\
\hline Jumlah & 19 & 100 \\
\hline
\end{tabular}

\section{PEMBAHASAN}

Gambaran Ketakutan Anak Usia Pra Sekolah Akibat Hospitalisasi Berdasarkan Usia

Berdasarkan tabel 1, karakteristikresponden berdasarkan usia pada penelitian ini dari 19 responden menunjukkan rata-rata usia responden 4,37 tahun. Pada usia prasekolah adalah masa golden age atau usia keemasan, perkembangan akan terhambat jika anak mengalami ketakutan dan kecemasan akibat hospitalisasi (Haryadi, 2015). Ketakutan dan kecemasan pada anak usia prasekolah ditunjukkan dengan reaksi anak yang cemas karena perpisahan, takut akan rasa sakit, kurang kontrol, marah ditunjukkan dengan tindakan rasa tidak terima yaitu menangis dan memberontak (James et al., 2012). Dalam penelitian ini peneliti memilih responden pada rentang usia prasekolah akhir yaitu 3-6 tahun. Secara teoretis pengalaman perasaan takut pada anak selama periode prasekolah umumnya lebih dominan dibandingkan dengan periode lain. Pada usia prasekolah merupakan fase perkembangan pada anak yaitu ketika anak mulai memiliki kesadaran tentang dirinya sendiri dan dapat mengenal beberapa hal yang dianggap berbahaya bagi anak tersebut akan mencelakai dirinya sendiri (Amalia et al., 2018)

Gambaran Ketakutan Anak Prasekolah Akibat Hospitalisasi Berdasarkan Jenis Kelamin

Berdasarkan penelitian ini didapatkan bahwa sebagian besar responden adalah perempuan sebanyak 11 responden dan responden laki-laki sebanyak 8 responden. Meskipun jenis kelamin bukan faktor dominan terhadap munculnya ketakutan dan kecemasan anak, namun ada penelitian yang mengatakan bahwa tingkat kecemasan dan ketakutan anak yang tinggi terjadi pada wanita dibandingkan dengan laki-laki yaitu 2:1 (Suryanti \& Yulistianti, 2012).

Gambaran Ketakutan Anak Usia Prasekolah Akibat Hospitalisasi

Dari hasil penelitian ini dapat diketahui tingkat ketakutan anak usia prasekolah yang menjalani hospitalisasi di Ruang Bakung Rumah Sakit Panti Waluyo Surakarta tahun 2020 menunjukkan bahwa distribusi frekuensi sangat takut pada anak sebanyak 14 reponden (73,7\%), pada anak tidak takut sama sekali sebanyak 5 responden (26,3\%). Berdasarkan observasi perawat bahwa respons anak saat mengalami ketakutan yaitu anak menjadi panik kemudian anak akan berusaha berlari atau menghindar lalu anak akan menangis dan menjerit untuk menghindari situasi yang menakutkan. Peneliti berpendapat bahwa tingkat ketakutan anak dipengaruhi oleh hospitalisasi. Hasil penelitian lain menunjukkan bahwa anak yang dirawat di rumah sakit cenderung memilki perasaan yang tidak nyaman karena lingkungan rumah sakit 
yang tetap sama dan membuat anak tidak bisa bebas bergerak sesuai dengan keinginannya (Derborah \& Westwood, 2012). Seperti yang diutarakan oleh (Legi et al., 2019) dalam penelitiannya bahwa anak usia prasekolah 3-6 tahun mengalami tingkat kecemasan yang berat. Sejalan pada penelitian (Dwitantya et al., 2016) bahwa seluruh responden anak usia prasekolah mengalami ketakutan, dengan nilai rata-rata 49,06. Hasil tersebut membuktikan bahwa anak hospitalisasi banyak mengalami stres sehingga rasa ketakutan tinggi.

\section{SIMPULAN DAN SARAN}

Hasil penelitian yang dilakukan di Rumah Sakit Panti Waluyo Surakarta menunjukkan bahwa rata-rata anak usia prasekolah yang menjalani rawat inap mengalami ketakutan dengan kategori sangat takut yaitu 11 responden (73,7\%).

Berdasarkan hasil penelitian tersebut diharapkan dapat dijadikan bahan masukan sebagai berikut.

1. Hasil penelitian dapat digunakan sebagai tambahan bahan informasi mengenai ketakutan anak akibat hospitalisasi.

2. Hasil penelitian ini dapat dijadikan masukan pentingnya mengetahui gambaran ketakutan anak usia prasekolah yang mengalami hospitalisasi dalam asuhan keperawatan;

3. Hasil penelitian ini diharapkan dapat digunakan sebagai referensi gambaran ketakutan anak akibat hospitalisasi

4. Hasil penelitian ini diharapkan dapat menambah pengetahuan tentang gambaran ketakutan anak usia prasekolah akibat hospitalisasi, serta dapat menjadi dasar penelitian selanjutnya.

5. Hasil penelitian ini diharapkan dapat menjadi bahan referensi bagi penelitian selanjutnya dan dapat ditambahkan intervensi sebagai terapi ketakutan pada anak.

\section{DAFTAR PUSTAKA}

Amalia, A., Oktaria, D., \& Oktavani. (2018). Pengaruh Terapi Bermain terhadap Kecemasan Anak Usia Prasekolah selama Masa Hospitalisasi. Majority, 7(2), 219225.

BPS. (2018). Katalog: 4203002. 312.

Derborah, N., \& Westwood, N. (2012). Westwood, N. (2012). The Health- Care Environtment Through The Eyes Of A ChildNo Title. International Journal of Nursing Practice, 18(1), 7-11.

Dwitantya, B. H., Kapti, R. E., \& Handayani, T. (2016). Efektifitas Permainan Boneka Tangan Terhadap Penurunan Ketakutan Anak Hospitalisasi pada Usia Prasekolah (3-6 Tahun) di RSUD Dr.R. Koesman Kabupaten Tuban. Majalah Kesehatan FKUB, 3(3), 128-136.

Haryadi. (2015). Karakteristik Masa Anak Usia Prasekolah. In wordpress.com.

James, J., Ghai, S., \& Sharman, N. (2012). Effectiveness Of "Animated Cartons" as A Distraction Strategy On Behavioural Response to Anxiety an Pain Perception Among Children Undergoing Venipunchure. Nursing and Midweifeny Research Journal., 8(3), 192-209.

Kyle, T., \& Carman, S. (2017). buku ajar keperawatan pediatri (2nd ed.). EGC.

Legi, R. J., Sulaiman, S., \& Purwanti, H. N. (2019). Pengaruh Storytelling Dan GuidedImagery Terhadap Tingkat Perubahan Kecemasan Anak Usia Prasekolah Yang Dilakukan Tindakan Invasif. Journal of Telenursing (JOTING), 1(1), 145-156. https://doi.org/https://doi.org/10.31539/ joting.vlil.496

Padila, Agusramon, \& Yera. (2019). Terapi Storytelling Dan Menonton Animasi Kartun Terhadap Ansietas. Journal of Telenursing (JOTING), 1(1), 51-66. 
Ramdaniati, S. (2011). Analisis Determinan Kejadian Takut Pada Anak Sekolah dan Prasekolah Yang Menjalani Hospitalisasi Di Ruang Perawatan Anak BLUD DR. Slamet Garut. Tesis, FIK Uviversitas Indonesia, Jakarta. Tesis.

Saputro, H., \& Fazrin, I. (2017). penurunan tingkat kecemasan anak akibat hospitalisasi dengan penerapan terapi bermain. Jurnal Konseling Indonesia, 3(1), 9-12. http:// ejournal.unikama.ac.id/index.php/JKI/ article/view/1972

Suryanti, S., \& Yulistianti, M. (2012). Suryanti, Sodikin. Yulistianti, M. (2012). Pengaruh
Terapi Bermain Mewarnai dan Origami Terhadap Tingkat Kecemasan Sebagai Efek Hospitalisasi Pada Anak Usia Prasekolah di RSUD dr.R. Goetheng Trauma di Brata Purbalingga. Jurnal Ilmiah Ilmu-Ilmu Kesehatan, 10(1), 3844.

Susanti, A., \& Hendika, S. (2013). Pengaruh Storytelling Terhadap Tingkat Kecemasan Anak Prasekolah yang Menjalani Hospitalisasi di RS DR. Djamil Padang. Jurnal Ilmu Kesehatan, 1(1), 2597-8594. https://doi.org/http:// dx.doi.org/10.33757/jik.v1i1.26 
